\title{
Trans Plantations
}

\section{Deniz Sözen}

\author{
$K-a-f-f-e-e$ \\ $K-a-f-f-e-e$ \\ trink nicht so viel Kaffee! \\ Nicht für Kinder ist der Türkentrank \\ schwächt die Nerven, macht dich blass und krank \\ Sei doch kein Muselmann, \\ der ihn nicht lassen kann! \\ $C-o-f-f-e-e$ \\ C-o-f-f-e-e \\ Don't drink so much coffee! \\ The Turk's Drink is not for children, \\ It weakens the nerves and makes you pale and sick. \\ Don't be a Muslim \\ Who can't help it $!^{1}$ \\ Karl Gottlieb Hering (1766-1853).
}

This German folk song about coffee, which three generations of the maternal side in my family, including myself, were taught in music education at school, issues an explicit warning against the consumption of coffee, which is denounced as the "Turk's drink". According to the song, Muslims cannot help but drink

1 For a more detailed discussion and English translation of the lyrics see Anidjar (2007). 


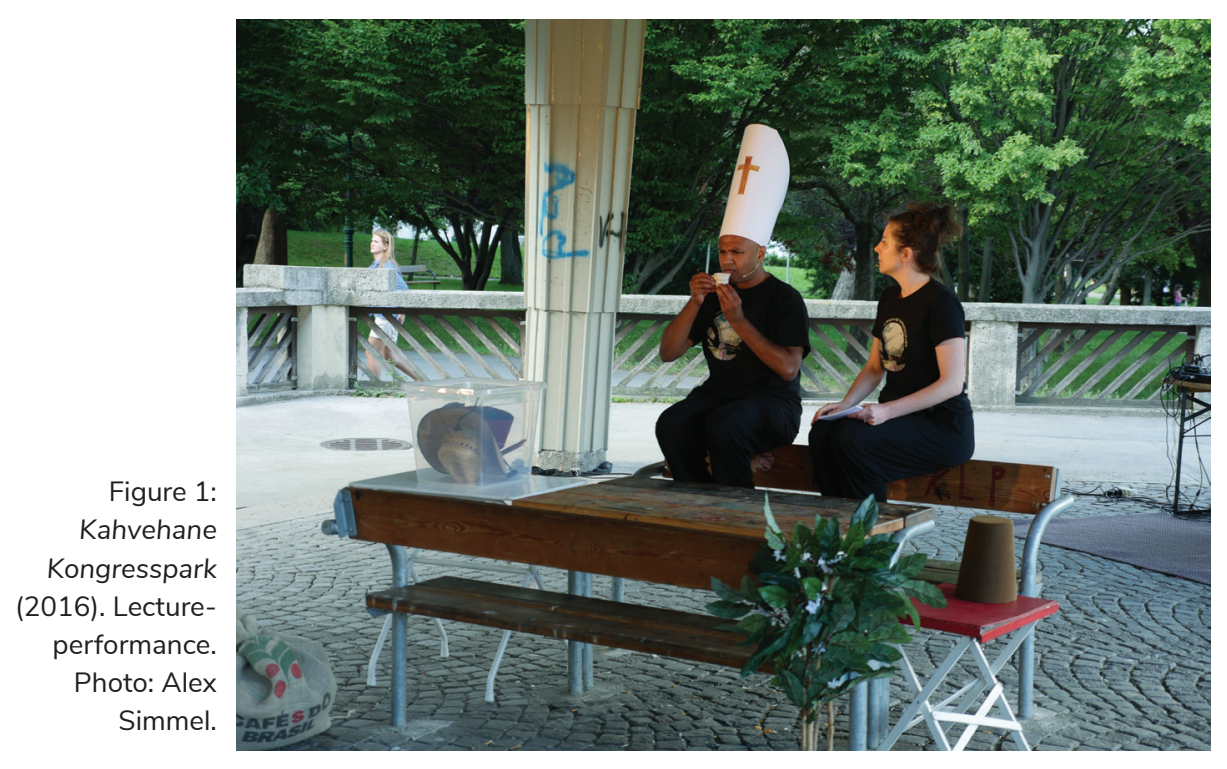

coffee and one should be careful not to drink too much of it, as it "makes you pale and sick" - attributes of weakness assigned to the Ottoman Turks, who had tried but failed to conquer Europe in the seventeenth century. The Turks were defeated at the gates of Vienna in 1683 but coffee, which they left behind when they fled the battlefield (Koz and Kuzucu 2013), was to become the most popular drink in the world. Today the demand for coffee beans is increasing worldwide. How does the consumption of coffee position us in relation to empire, colonial history and notions of the local and the global? Or, to return to the German folk song, how "Turkish" is your coffee?

These were some of the central questions that arose from two discrete, yet interrelated projects which formed part of the practice element of my doctoral research The Art of Un-belonging: Kahvehane Kongresspark (2016), a temporary café featuring specially designed ceramic cups/saucers and a site-specific performance in public space, and Trans Plantations (2018), an installation of cups/saucers and coffee beans cast in porcelain in combination 


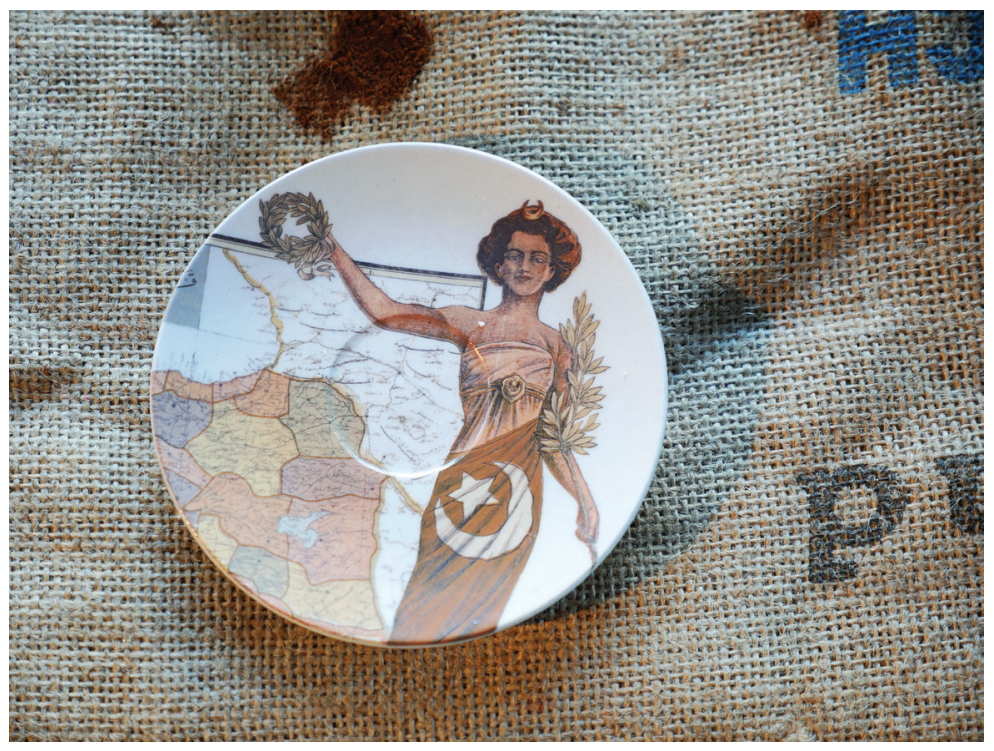

Figure 2:

Kahvehane

Kongresspark

(2016).

Temporary coffeehouse.

Ceramic coffee cup and saucer (decal design: Ottoman). Photo: Deniz Sözen.

with an audio-visual element. Experimenting with transcultural performance, multilingual storytelling and collaborative processes of creative writing and artmaking, both projects present a multiplicity of viewpoints and voices that question the Eurocentric imaginary and explore the colonial history of and human entanglements with coffee.

Honduras, Brazil, Java, Columbia?

The label says coffee comes from Latin America.

Is coffee a she, like the plant in German: die Pflanze, die Bohne.

Or a he? As, der Samen.

Is coffee a seed or a fruit?

A cherry, a berry or a bean?

Where does coffee come from?

Africa? Mocha? India?

Peru? Guatemala? Nicaragua?

The label says: Latin America.

If coffee is Brazilian, why is she called Arabica?

Is coffee a migrant? A Muslim? A trans-plant? 
As we follow the path of coffee, we embark on a journey that takes us around the world, travelling through time and space. The lecture-performance as part of Kahvehane Kongresspark does not tell a linear story of coffee. It starts in the here and now: in the middle or perhaps towards the end of the "Anthropocene" or, in Haraway's (et al. 2016) words, the "Plantationocene". Aiming to bring awareness to this relation, the narration of coffee's transplantation trajectory begins at a coffee plantation in Minas Gerais, Brazil.

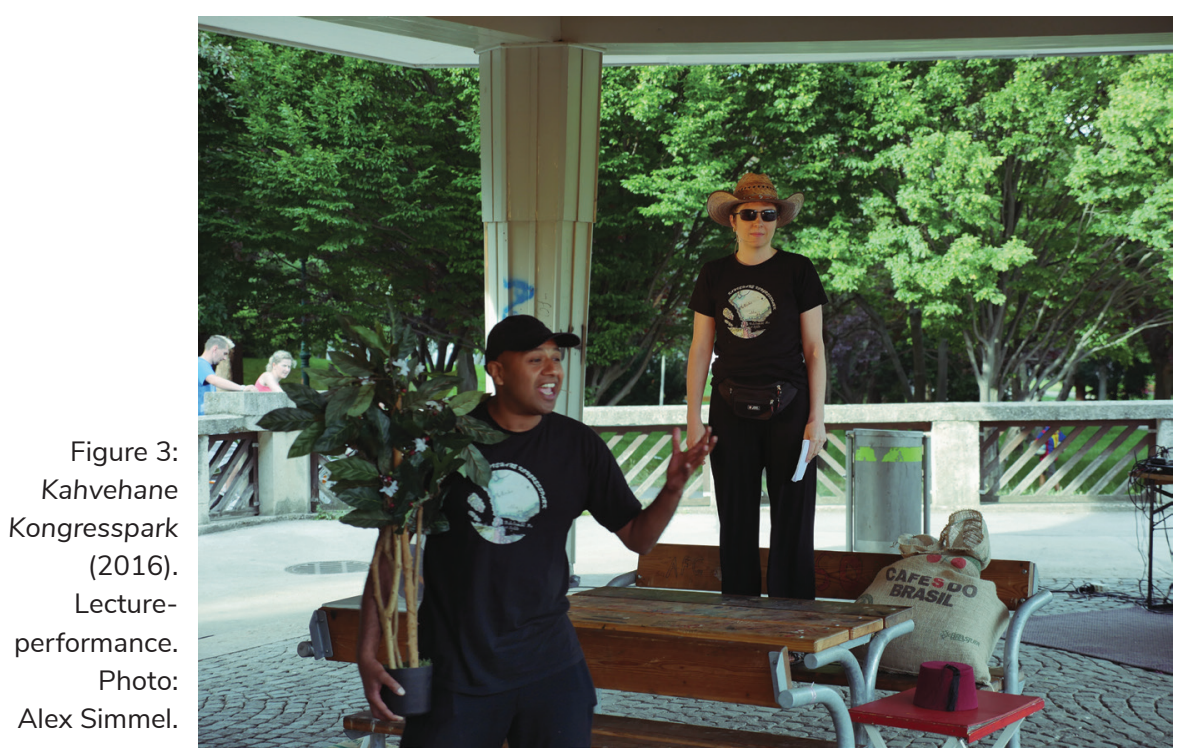

This scene, which is set in Brazil, aims to shed light to the entanglement of coffee and colonialism, i.e. the history of slavery and plantations as part of the colonial enterprise. Bharatanatyam artist and actor Shane Shambhu plays a coffee plantation worker named Ramiro, while I impersonate the plantation owner and CEO of a multinational coffee company exploiting its coffee workers in Brazil. The script is based on factual information: numerous scandals have exposed the exploitation and abuse of coffee workers in Brazil (Hodal 2016). Owing to the legacy of 
slavery and colonialism, today Brazil is the largest exporter of coffee, accounting for about one-third of the global market. ${ }^{2}$

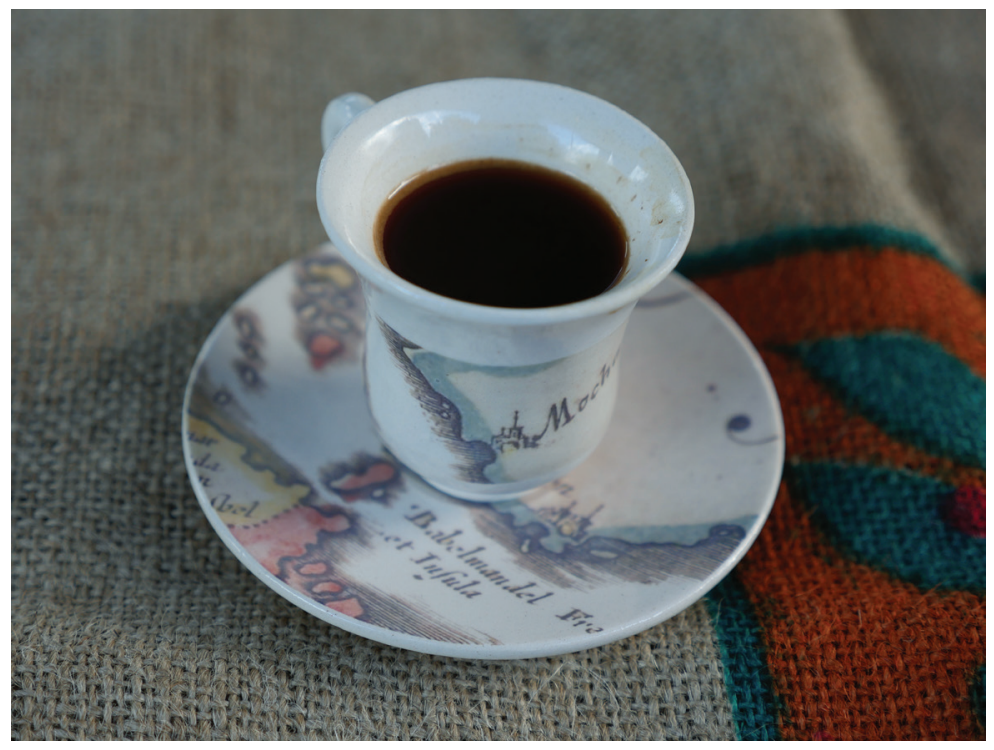

Figure 4:

Kahvehane

Kongresspark

(2016).

Temporary coffeehouse.

Ceramic coffee cup and saucer (decal design: Port of Mocha). Photo: Deniz Sözen.

Starting with the cultivation of sugarcane (which proved to be one of the most profitable crops) in the Caribbean from the late seventeenth century onwards, the plantation was a system that was replicated widely throughout the Americas. In her insightful book Sowing Empire: Landscape and Colonization, the art historian Jill H. Casid (2005) reminds us that the construction of the (monocultural) plantation required the clearing and removal of native, biodiverse forests in order to make room for the colonizers to cultivate transplanted cash crops, such as sugar cane or coffee. As she states, "ideologically and discursively, plantation was often used as a synonym for colony” (Casid 2005: 7).

2 An excerpt of the performance can be watched here: https://vimeo. com/175368263. 
The plantation system is constitutive of coloniality, which Mignolo (2011) describes as a complex matrix of power which serves to dominate and control through the fabrication and management of knowledge, driven by imperialism, Christianity and capitalism. According to him, modernity and coloniality - as "the darker side of Western Modernity" - are inextricably linked. As he points out, it was through the development of the colonial matrix of power and the Industrial Revolution that the meaning of nature transformed into "natural resources" (Mignolo 2011: 12). The plantation system was based on the transplantation of plants, ${ }^{3}$ humans and animals, who were uprooted and exploited as profitable "resources", generating a new global market. As Mignolo (2011: 12) observes, "this transformation resulted in extensive enslaved trade that transformed human life into a commodity - for the owner of the plantation, of the mine, and, later on, of the industry". In this sense, the plantation could

Figure 5:

Kahvehane

Kongresspark

(2016). Edition

of 100 glazed

Kütahya ceramic cups and saucers and nine ceramic decal designs.

Photo: Deniz

Sözen.

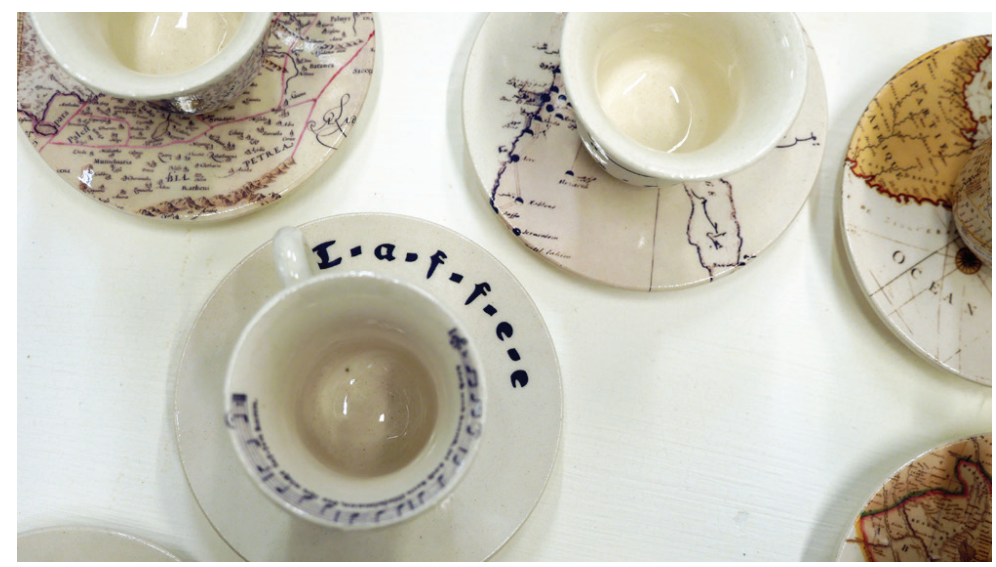

3 To give an example of the colonial practice of transplantation, a specific type of sugar cane from Tahiti that had been transferred to the royal botanical garden in Paris in the late 1800s was subsequently transplanted and cultivated as a cash crop in the French colonies of Mauritius, the Réunion islands, French Guiana, Martinique etc. (see Casid 2005: 33). 
be seen as a precursor to industrial capitalism - an observation that is shared by Haraway (et al. 2016) and expressed in the concept of the "Plantationocene".

According to the herbalist and anthropologist Jason T.W. Irving (2018: 131), the search for new biological resources, such as crops or plants and the appropriation of local and indigenous knowledge, which could be commodified (a practice which is called bioprospecting), was "a fundamental part of European colonial expansion". Through the economic promise of lucrative trade in plants, botanists became "the agents of empire" (David Mackay, as quoted in Schiebinger 2004: 11) and, as Sita Balani (2018: 231) states in her essay "From Botany to Community: A Legacy of Classification", the imperial science of botany became key to the development of "a taxonomic imagination" in Europe.

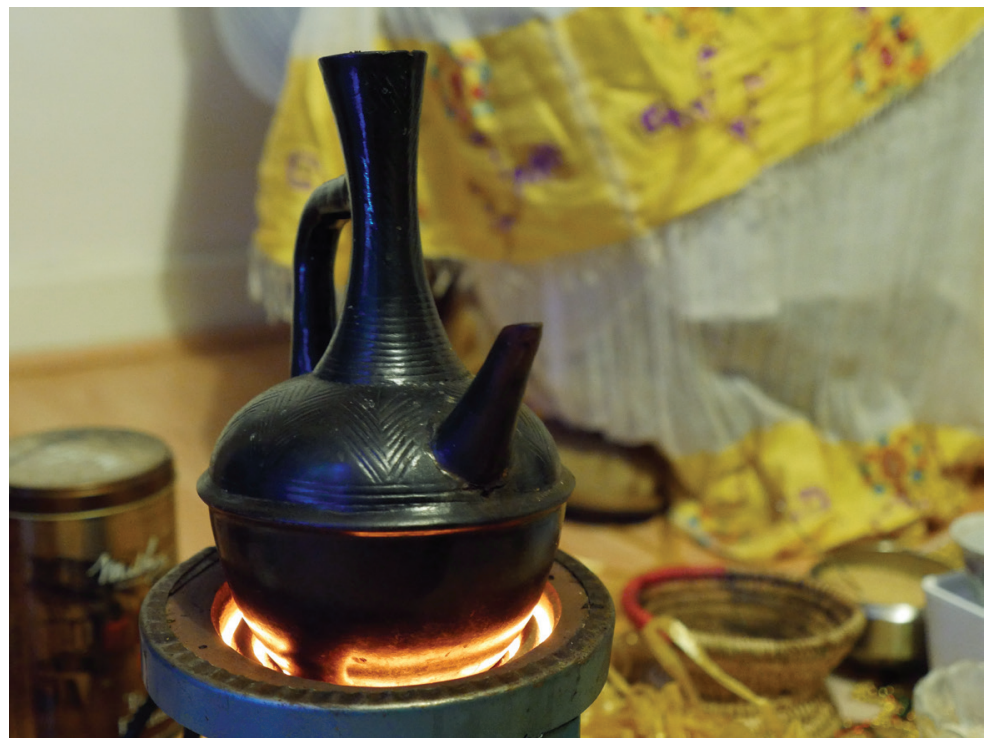

Figure 6: Ethiopian coffee ceremony at Mesfin Ali's home in London, 2018. 
Wrongly assuming that the coffee plant was indigenous to the Arabian Peninsula, the Swedish botanist Carl Linnaeus (17071778) classified the plant as Coffea arabica. ${ }^{4}$ However, genetically coffee's arabica variety can be traced back to a small tree or scrub growing in the rainforest canopies of a region that today is known as Ethiopia (formerly Abyssinia). Even though exact dates and circumstances remain obscure, it is now widely agreed that from there coffee was transported across the Red Sea to Yemen, where its cultivation is well documented. In Yemen, Sufi monks, who discovered that drinking coffee helped them to stay

Figure 7:

Scan of a handful of green, unroasted coffee beans from Ethiopia.

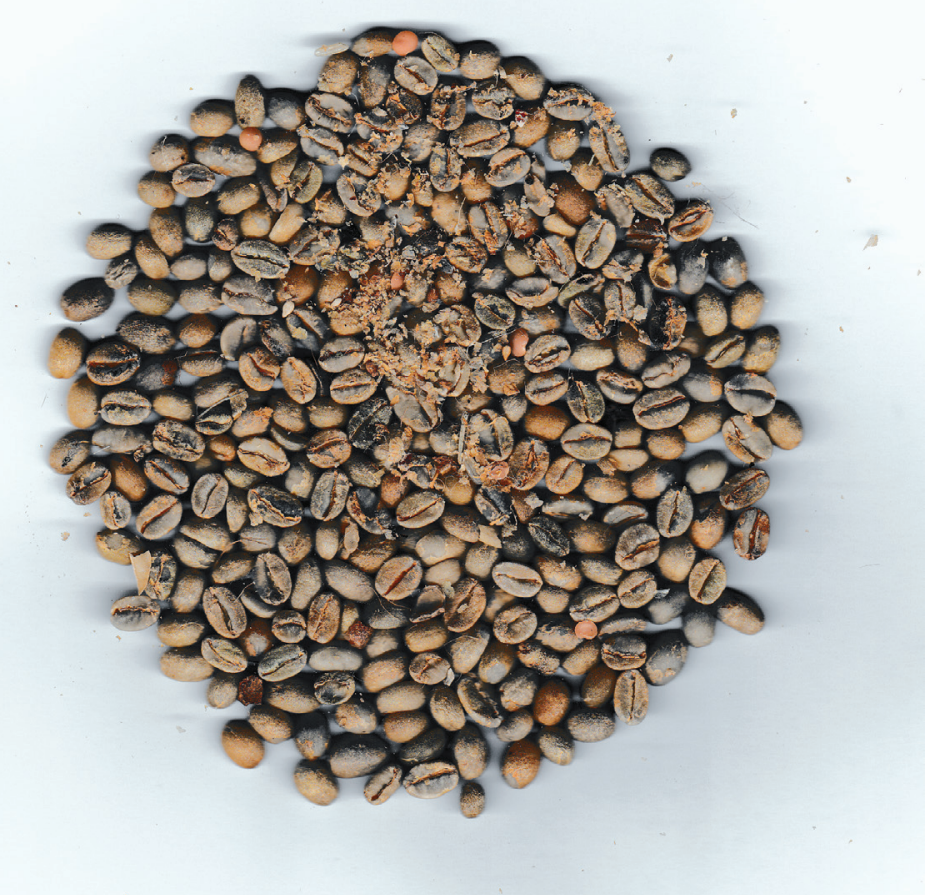

4 Linnaeus's binominal nomenclature established the principles of modern botanical taxonomy and is regarded as an important mechanism of the colonial enterprise (Schiebinger and Swan 2005). 
up for their midnight prayers, quickly appropriated the "African drink", naming it al-qahwa after an Arabic word for wine (Pendergrast 2010: 6). It is likely that the name "coffee" derives from Arabic al-qahwa, ${ }^{5}$ which later transformed to kahve in Turkish.

The temporary Kahvehane (coffeehouse) at the Vienna Kongresspark provided the open-air stage for the lecture-performance which explored the many legends about the origins of coffee, tracing its journey from Ethiopia, through the Arabian Peninsula and the Ottoman Empire, and its transplantation across the entire globe. Out of this project grew another incarnation of my artistic exploration of coffee: the multi-part installation Trans Plantations (2018), which combines an installation of unglazed "Turkish" coffee cups and saucers with a silent video of colonial maps that are projected onto the cups alongside a discrete, yet related, installation of coffee beans cast in porcelain, accompanied by a multilingual soundtrack. Unlike Kahvehane Kongresspark, this project was conceived for an interior space, although not necessarily for a gallery environment. Approaching the heap of white coffee beans cast in porcelain placed at the centre of a dark cubic plinth, the onlooker hears voices murmuring in multiple languages. This is the voice of coffee - of the plant and the bean - speaking in the first person, in his or her respective mother tongue, evoking memories of the plantation, his or her relation to the soil and climate (change), interactions with humans, observations about conditions of labour, trade, transportation and different culturally specific ways of production and consumption. ${ }^{6}$

5 As the coffee historian Mark Pendergrast (2010) points out, amongst other possibilities, it has also been suggested that the name "coffee" could equally be connected to Kaffa, a region in Ethiopia, or quwwa, Arabic for power.

6 Link to the multilingual soundtrack: https://soundcloud.com/ user-530978425/trans-plantations-version-june-2018. 


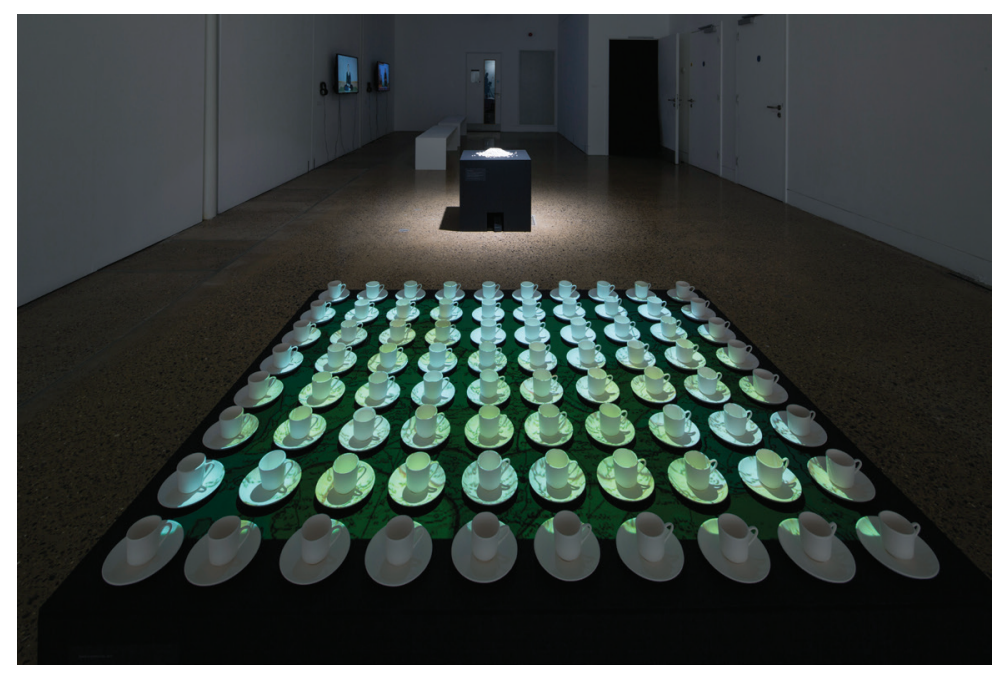

Figure 8: Trans Plantations (2018). Installation shot, London Gallery West, 2018. Photo: David Freeman.

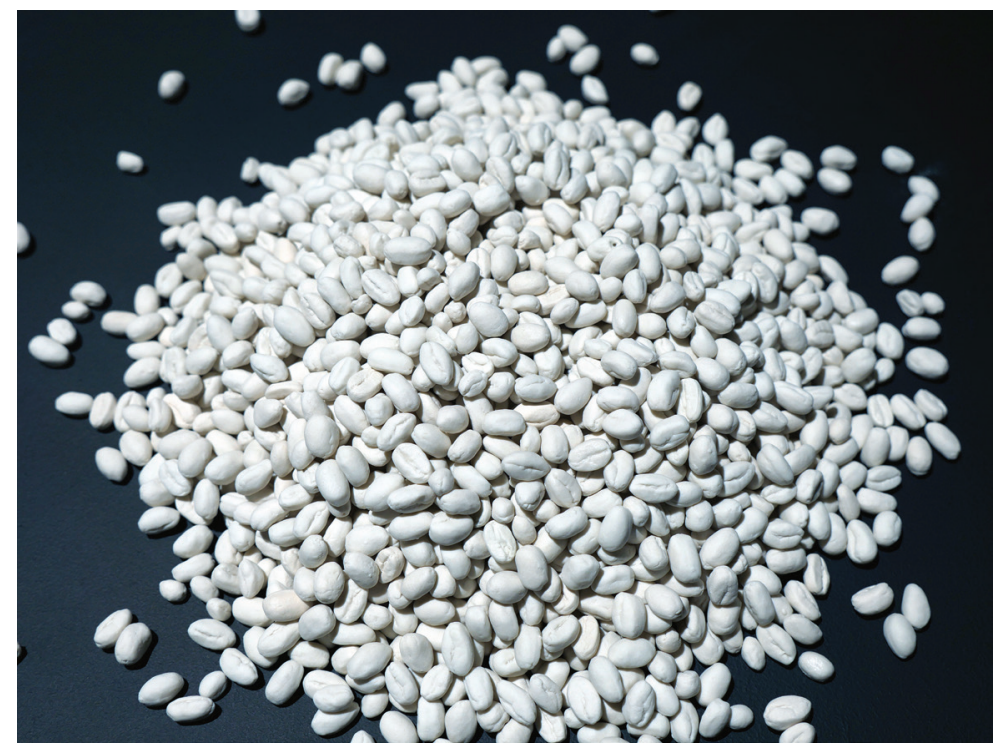

Figure 9: Trans Plantations (2018). Coffee beans cast in porcelain. Photo: Deniz Sözen. 
If we return to the aforementioned German folk song and associations of coffee with Turkish-ness (and the appropriation of coffee by Turkish nationalism), it seems ironic that currently most "Turkish" coffee brands are in fact made from coffee beans grown in Brazil. This phenomenon of long-distance relationships between localities of production and consumption is characteristic of the impact of globalization, which according to John Tomlinson (1999: 123) "does clearly undermine a close material relationship between the provenance of food and locality". Our sense of connection to the local and global has been altered significantly through the availability of food from distant regions in our supermarket shelves. It is precisely the connection between food, identity and belonging which had triggered my interest in coffee.

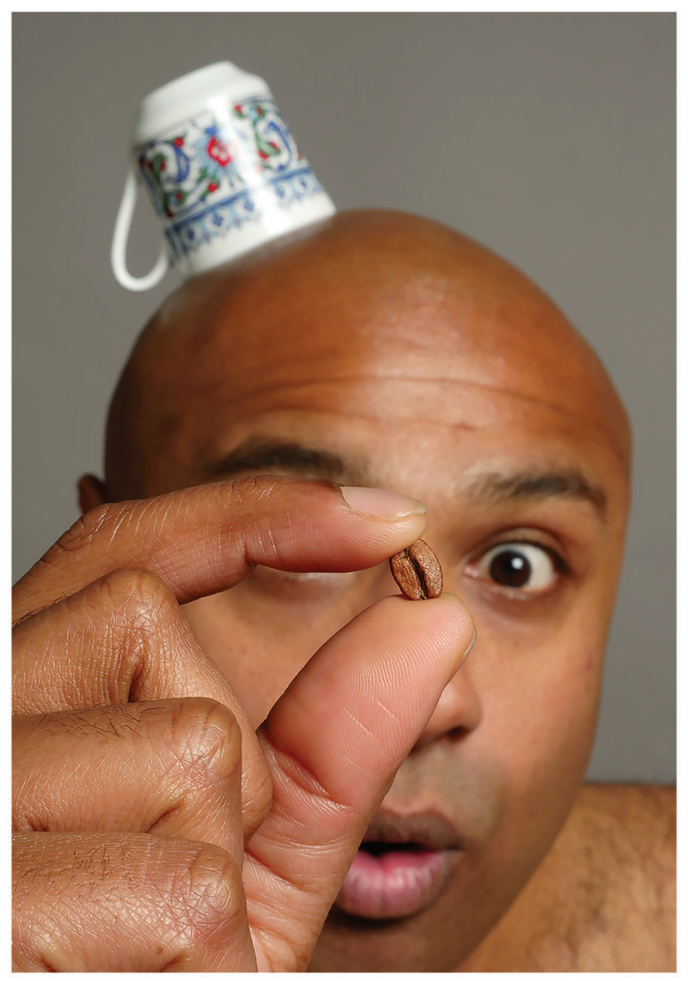

Figure 10:

Kahvehane Kongresspark (2016). Poster. Photo: Deniz Sözen. 
Coffee is intensely linked to memory and identity - individual and collective. As a popular Turkish folk saying goes, "a cup of coffee will be remembered for forty years". Clearly, it is not the coffee per se which will be remembered, but rather the relation to those we are sharing the coffee with. And yet, despite this relational aspect, the conditions of labour of those who planted, picked and processed the coffee will rarely enter our consciousness.

Embarking on research about coffee's colonial and naturecultural history, which informed the writing of the scripts for the lecture-performance Kahvehane Kongresspark and the soundtrack of Trans Plantations, made me aware of coffee's agency as a global trans-plant and instigated further research in relation to colonial practices of transplantation and labour exploitation. By serving coffee to the public, the temporary coffeehouse and public art intervention Kahvehane Kongresspark aimed to shift the focus to our interconnectedness and entanglement with matter - coffee and ceramics. In contrast to the ceramic cups and saucers specially designed for Kahvehane Kongresspark, the porcelain cups and saucers that formed part of the installation Trans Plantations were unglazed and therefore not functional. Only fired once, the slip cast white porcelain cups and saucers form a canvas onto which fragmented images of colonial maps are projected. The porcelain coffee beans are made of the same material, unglazed porcelain, yet fired at a slightly higher temperature. In Trans Plantations, the objects and matter become "theatrical" elements that immerse the viewer into a sensory experience, which is further enhanced through a video projection and a multilingual narrative/ soundtrack. The voice recordings of "coffee" speaking in various languages would be mostly unintelligible to a monolingual English audience, challenging the universal standardization of Anglo-American English as the global lingua franca of contemporary art. By tracing coffee's imperial history marked by processes of alienation and deterritorialization - as the multilayered story of 
a trans-plant - my artworks make the viewer appreciate that we are all entangled in a web of relations: in order to acknowledge that we all belong to the earth, yet the earth does not belong to us.

This essay is based on my doctoral thesis The Art of Un-belonging (University of Westminster, 2019).

DENIZ SÖZEN is a visual artist, researcher and educator. She can be reached via www.denizsoezen.com.

\section{References}

Anidjar, Gil. 2007. “Chapter Thirteen”. In The Present as History:

Critical Perspectives on Global Power, edited by Nermeen Shaikh, 225-254. New York: Columbia University Press. http://www.jstor. org/stable/10.7312/shai14298.17.

Balani, Sita. 2018. "From Botany to Community: A Legacy of Classification". In Uriel Orlow, Theatrum Botanicum, edited by Shela Sheikh and Uriel Orlow, 229-235. Berlin: Sternberg Press.

Casid, Jill H. 2005. Sowing Empire: Landscape and Colonization. Minneapolis, MN: University of Minnesota Press.

Haraway, Donna and Noboru Ishikawa, Scott F. Gilbert, Kenneth Olwig, Anna L. Tsing and Nils Bubandt. 2016. "Anthropologists Are Talking - About the Anthropocene". Ethnos 81(3), 535-564. http://dx.doi.org/10.1080/00141844.2015.1105838.

Hodal, Kate. 2016. “Nestlé Admits Slave Labour Risk on Brazil Coffee Plantations". The Guardian, 2 March. Accessed 12 March 2019. https://www.theguardian.com/global-development/2016/mar/02/ nestle-admits-slave-labour-risk-on-brazil-coffee-plantations. Irving, Jason T.W. 2018. "Decentering European Medicine: The Colonial Context of the Early History of Botany and Medicinal Plants". In Uriel Orlow, Theatrum Botanicum, edited by Shela Sheikh and 
Uriel Orlow, 129-136. Berlin: Sternberg Press.

Koz, M. Sabri and Kemalettin Kuzucu. 2013. Turkish Coffee. Translated from the Turkish by Mary P. Işın. Yapı Kredi Yayınları: Istanbul. Mignolo, Walter. 2011. The Darker Side of Western Modernity: Global Futures, Decolonial Options. Durham, NC: Duke University Press.

Pendergrast, Mark. 2010. Uncommon Grounds: The History of Coffee and How It Transformed our World. New York: Basic Books.

Schiebinger, Londa. 2004. Plants and Empire: Colonial Bioprospecting in the Atlantic World. Cambridge, MA: Harvard University Press.

Schiebinger, Londa and Claudia Swan, eds. 2005. Colonial Botany:

Science, Commerce, and Politics in the Early Modern World. Philadelphia, PA: University of Pennsylvania Press.

Tomlinson, John. 1999. Globalization and Culture. Oxford: Polity. 